\title{
Efektifitas Pertumbuhan Benih Betok (Anabas testudineus) Menggunakan Vitamin C dan D sebagai Suplemen Pakan
}

\author{
Growth Effectivity of Climbing Perch (Anabas testudineus) Used Vitamin C and D as Feed \\ Suplement \\ Helmizuryani Helmizuryani ${ }^{1 *}$, Meika Puspitasari ${ }^{1}$, Khusnul Khotimah ${ }^{1}$ \\ ${ }^{1}$ Prodi Budidaya Perairan, Universitas Muhammadiyah Palembang, Kota Palembang, \\ Sumatera Selatan 30116 \\ ${ }^{*}$ Penulis untuk korespondensi: helmi_zuryani@um-palembang.ac.id
}

\begin{abstract}
The added of vitamin in feed is expected to increase the feed efficiency, growth and survival of climbing perch (Anabas testudineus). This research was conducted to analysis the effectivity of vitamin supplement to increased the growth and survival of climbing perch (Anabas testudineus). The method used was an experimental method, with Completely Randomized Design (CRD), and three levels of treatment. The research carried out at Fish Hatchery Unit named Mulia on Plaju district, Palembang city. It's started from March until May 2018. The treatment used vitamin C and D gives the doses differentiation, that were $V_{1}$ (doses of vitamin C $125 \mathrm{mg} / \mathrm{kg}$ feed), $V_{2}$ (doses of vitamin D $375 \mathrm{mg} / \mathrm{kg}$ feed), and $\mathrm{V}_{3}$ (doses of vitamin $\mathrm{C}+\mathrm{D} 125 \mathrm{mg} / \mathrm{kg}$ feed and $375 \mathrm{mg} / \mathrm{kg}$ feed). The growth analysis parameter was the growth of length, weight, and survival rate. The results that showed the best growth and survival of climbing perch (Anabas testudineus) were vitamin $\mathrm{D}$ and $\mathrm{C}$, where best mass on $\mathrm{V}_{3}$ about $3,89 \mathrm{~g}$. While the lowest on $\mathrm{V}_{1}$ about 2,7g. The best growth length on $\mathrm{V}_{3}$ about $4,61 \mathrm{~cm}$, otherwise the weakest on $\mathrm{V}_{1}$ about $3,85 \mathrm{~cm}$. The survival rate was highest on $\mathrm{V}_{3}$ about $88,33 \%$ and the lowest on $\mathrm{V}_{2}$ about $83,33 \%$. Vitamin required for a fish body to carry out metabolism, but if overuses could be hipervitaminosis.
\end{abstract}

Keywords: climbing perch, growth, juvenile, vitamin A and D

\begin{abstract}
ABSTRAK
Pemberian suplemen berupa vitamin ke dalam pakan dengan dosis yang berbeda diharapkan dapat meningkatkan efisiensi pakan dan pertumbuhan serta kelangsungan hidup benih ikan betok Anabas testudineus) Penelitian ini dilakukan untuk menentukan efektifitas suplemen berupa vitamin $\mathrm{C}$ dan D yang ditambahkan pada pakan ikan untuk meningkatkan pertumbuhan dan kelangsungan hidup benih ikan betok (Anabas testudineus). Penelitian ini dilaksanakan di unit pembenihan rakyat (UPR) Mulia, Jalan Kapten Abdullah. Kec. Plaju Palembang, pada bulan Maret sampai dengan Mei 2018. Metode penelitian menggunakan Rancangan Acak Lengkap (RAL) dengan 3 perlakuan dan 3 ulangan dengan perlakuan dosis vitamin $V_{1}=$ Penambahan vitamin D Dosis $125 \mathrm{mg} / \mathrm{kg}$ pakan $\mathrm{V}_{2}=$ Penambahan vitamin $\mathrm{C}$ dosis $375 \mathrm{mg} / \mathrm{kg}$ pakan dan $\mathrm{V}_{3}=$ Penambahan kombinasi vitamin $\mathrm{D}$ dan $\mathrm{C}$ dengan dosis $125 \mathrm{mg} / \mathrm{kg}$ dan $375 \mathrm{mg} / \mathrm{kg}$ pakan. Parameter yang diamati adalah pertumbuhan panjang dan berat serta kelangsungan hidup. Hasil penelitian menunjukkan bahwa pemberian vitamin pada pakan ikan dengan dosis yang berbeda memberikan pengaruh terbaik terhadap pertumbuhan dan kelangsungan hidup pada perlakuan $\mathrm{V}_{3}$ sebesar $3,89 \mathrm{~g}$, sedangkan pertumbuhan berat terendah pada $\mathrm{V}_{1}$ penambahan vitamin $\mathrm{D}$ sebesar $2,70 \mathrm{~g}$, pertumbuhan panjang yang tertinggi terdapat pada
\end{abstract}


perlakuan V3 yaitu penambahan vitamin $\mathrm{C}$ dan $\mathrm{D}$ sebesar $4,61 \mathrm{~cm}$ sedangkan pertumbuhan panjang terendah terdapat pada perlakuan V1 yaitu penambahan vitamin D sebesar 3,85 cm.dan nilai kelangsungan hidup tertinggi terdapat pada perlakuan V3 sebesar 88,33\%, sedangkan kelangsungan hidup benih ikan betok terendah terdapat pada perlakuan V2 yaitu penambahan vitamin $\mathrm{C}$ sebesar $83,33 \%$.Vitamin sangat diperlukan oleh tubuh untuk menjalankan berbagai fungsi metabolisme, namun jika terjadi kelebihan vitamin akan mengakibatkan hipervitaminosis.

Kata kunci: benih ikan betook, pertumbuhan, vitamin A dan D

\section{PENDAHULUAN}

Ikan betok merupakan ikan asli perairan Indonesia yang cukup digemari oleh masyarakat. Tingginya tingkat konsumsi ikan betok ini disebabkan karena rasa dagingnya yang enak dan kandungan gizi yang terkandung didalamnya. Berangkat dari hal tersebut, didukung oleh semakin meningkatnya kesadaran masyarakat akan pentingnya konsumsi ikan, menyebabkan terjadinya peningkatan permintaan ikan betok di masyarakat. Secara umum, distribusi ikan betok sendiri tersebar di wilayah Asia Selatan dan Asia Tenggara dengan habitat lingkungan perairan sungai, rawa dan danau. Ikan ini mampu hidup di dibawah $\mathrm{pH} 4$ dengan salinitas 11,5 permil (Prianto et al. 2014).Di indonesia sendiri, Ikan betok tersebar di Kalimantan, Sumatera dan Jawa (Helmizuryani et al. 2017).

Kegiatan budidaya ikan betok sudah dilakukan dengan pakan komersil sebagai sumber makanan utama untuk mendukung pertumbuhannya.Penelitian (Helmizuryani and Muslimin 2016) menyatakan benih ikan betok dapat merespon pakan pellet (komersil) berkadar protein 32\% sebesar 1, $43 \mathrm{~cm}$ untuk panjang ikan dan 2,68 gram untuk berat ikan betok denganbaik. Pemberian pakan komersil diberikan dengan asumsi bahwa kandungan zat-zat yang dibutuhkan sudah tersedia didalam pakan tersebut. Rendah dan tingginya pertumbuhan pada ikan dipengaruhi oleh kemampuan ikan merespon pakan yang dimanfaatkan untuk pertumbuhan, menurut (Asyari 2007), makanan yang didapat oleh ikan terutama digunakan untuk pergerakan, pemulihan organ tubuh yang rusak, setelah itu kelebihan makanan yang didapatkan digunakan untuk pertumbuhan. Sedangkan untuk kelangsungan hidupnya semua jenis ikan membutuhkan zat-zat gizi yang baik. Jumlah dan komposisi zat-zat gizi tersebut harus di perhatikan agar dapat memenuhi kebutuhan ikan. Selain kualitas, jumlah dan komposisi zat-zat gizi yang harus ada dalam pakan ikan seperti karbohidrat, lemak, protein, vitamin, dan mineral. Pemberian pakan dengan tambahan suplemen atau bahan tambahan lain dapat menjadi alternatif upaya peningkatan pertumbuhan.

Vitamin merupakan salah satu zat tambahan yang dapat menjadi alternatif untuk ditambahkan kedalam pakan untuk meningkatkan respon pertumbuhan ikan betok. Vitamin merupakan nutrien organik yang dibutuhkan dalam jumlah kecil bagi sejumlah fungsi biokimia dan umumnya tidak dapat disintesis oleh tubuh sehingga harus dipasok dari pakan. (Dewantara and Syamsiah 2008). Penambahan satu atau dua jenis vitamin ke dalam pakan ikan diharapkan dapat meningkatkan pertumbuhan melalui peningkatan kualitas pakan. Salah satu vitamin yang dapat ditambahkan kedalam pakan adalah vitamin C dan vitamin D. Vitamin C berperan dalam menormalkan fungsi kekebalan, mengurangi stres dan mempercepat penyembuhan luka. Vitamin $\mathrm{D}$ berperan dalam mencukupi kebutuhan kalsium. Kebutuhan vitamin $\mathrm{C}$ dan $\mathrm{D}$ untuk mendapatkan pertumbuhan yang optimal sangat bervariasi tergantung pada spesies dan umur atau ukuran ikan, laju pertumbuhan dan fungsi metabolisme. Menurut (Zulkarnain 2017) vitamin C memiliki kandungan antioksidan yang sempurna dan juga memiliki kemampuan 
anti stress, vitamin C merupakan komponen alami yang dapat mengubah efek negative dari metabolisme energi pada ikan. Vitamin C bukan merupakan sumber tenaga, tetapi dibutuhkan oleh ikan sebagai katalisator terjadinya proses metabolisme di dalam tubuh, untuk pertumbuhan normal, kelangsungan hidup dan reproduksi. Selain vitamin $\mathrm{C}$, tubuh juga memerlukan vitamin D yang berguna untuk proses penyerapan kalsium dan fosfat dalam tubuh. Dalam proses pertumbuhannya ikan juga memerlukan kalsium dan fosfat yang cukup, defisiensi terhadap kalsium dan fosfat tidak hanya mengakibatkan pertumbuhan ikan yang terhambat tetapi efisiensi pakan juga rendah serta dalam jangka panjang ikan akan mengalami malformation. Berdasarkan penelitian (Sunarto 2008), penambahan vitamin C dengan dosis $375 \mathrm{mg} / \mathrm{kg}$ pada pakan dapat meningkatkan laju pertumbuhan harian, respon imun, efesiensi pakan dan daya tahan ikan betok, sedangkan untuk penggunaan vitamin $\mathrm{D}$ dosis $125 \mathrm{mg} / \mathrm{kg}$ meningkatkan kualitas pertumbuhan larva patin yang disuplementasi vitamin D pada artemia. Untuk itu perlu dilakukan penelitian mengenai kebutuhan vitamin $\mathrm{C}$ dan $\mathrm{D}$ yang optimal terhadap pertumbuhan ikan betok. Tujuan dari penelitian ini adalah untuk menentukan vitamin yang terbaik untuk ditambahakan pada pakan ikan terhadap pertumbuan dan kelangsungan hidup ikan Betok.

\section{BAHAN DAN METODE}

Penelitian ini telah dilaksanakan di unit pembenihan rakyat (UPR) Mulia, Jl. Kapten Abdullullah. Lr. Mulia 1. Kel. Talang Bubuk. Kec.Plaju Palembang selama 60 hari dari bulan Maret sampai dengan bulan Mei 2018.

Bahan yang digunakan meliputi benih ikan betok yang didapatkan dari hasil perkawinan induk berusia 40 hari.Pakan yang digunakan adalah pelet dengan kandungan protein sebesar 35\%, vitamin D (Calvid D) dan vitamin C (Max-C
500).Sedangkan Alat yang digunakan dalam penelitian ini meliputi, gunting, alat tulis berupa pena, pensil, spidol, waring sebanyak 9 buah dengan ukuran (50x 50x120) $\mathrm{cm}^{3}$, kayu dengan panjang $4-5$ $m$ sebanyak 9 buah yang digunakan untuk mengikat waring, penggaris untuk mengukur panjang tubuh benih ikan betok, timbangan digital digunakan untuk mengukur bobot badan ikan, tali tambang berukuran kecil untuk mengikat waring ke kayu, serokan halus, $\mathrm{pH}$ meter untuk mengukur $\mathrm{pH}$, DO meter untuk mengukur oksigen, dan untuk mengukur suhu.

Benih ikan betok (A. testudineus) yang telah diukur panjang dan berat nya di tebar dalam waring pada sore hari. Setiap waring ditebar benih ikan betok sebanyak 20 ekor. Pakan yang diberikan pada masing-masing perlakuan berupa pakan pellet yang dicampurkan dengan vitamin $\mathrm{D}$, C dan campuran kedua vitamin. Vitamin D dan $\mathrm{C}$ dengan dosis sesuai takaran dilarutkan dengan menggunakan air $100 \mathrm{ml}$, setelah itu disemprotkan ke dalam pakan dengan dosis yang telah ditentukan. Kemudian pellet yang telah disemprot dengan menggunakan vitamin sesuai perlakuan dikering anginkan \pm 30 menit terlebih dahulu baru diberikan ke benih ikan betok. Ikan betok di pelihara selama 60 hari di dalam waring, dengan pemberian pakan secara adsatitation yang diberi makan 3 kali sehari yaitu pada pukul 08.00, 12.00 dan 17.00. Pengamatan yang dilakukan berupa pengamatan pertumbuhan dan kelangsungan hidup ikan betok. Pengamatan pertumbuhan dilakukan 10 hari sekali dengan menimbang ikan betok. Ikan yang ada dalam wadah penelitian ditimbang total berat biomas (populasi). Jumlah ikan dihitung serta bila ada yang mati ditimbang untuk menentukan persentase kelangsungan hidupnya.

Penelitian ini dilakukan dengan menggunakan metode eksperimen, dengan menggunakan Rancangan Acak Lengkap (RAL) yang masing-masing perlakuan di ulang sebanyak 3 kali. Adapun tingkat faktor perlakuan sebagai berikut: 

$\mathrm{V}_{1}=$ Penambahan vitamin $\mathrm{D}$ dosis 125 $\mathrm{mg} / \mathrm{kg}$ pakan
$\mathrm{V}_{2}=$ Penambahan vitamin $\mathrm{C}$ dosis 375 $\mathrm{mg} / \mathrm{kg}$ pakan
$\mathrm{V}_{3}=$ Penambahan vitamin $\mathrm{D}$ dan $\mathrm{C}$ dosis $125 \mathrm{mg} / \mathrm{kg}$ dan $375 \mathrm{mg} / \mathrm{kg}$ pakan

\section{Analisis Data}

Data yang terkumpul kemudian diolah dengan beberapa parameter yaitu:

1. Pertumbuhan panjang ikan menurut (Effendi 2004) dengan menggunakan rumus sebagai berikut.

$$
\boldsymbol{L}=\boldsymbol{L} \boldsymbol{t}-\boldsymbol{L o}
$$

Keterangan:

$\mathrm{L}=$ Pertumbuhan panjang benih ikan

Lt $=$ Panjang benih ikan rata-rata pada akhir pemeliharaan

Lo $=$ Panjang benih rata-rata

2. Pertumbuhan berat ikan menurut (Effendi 2004) dengan menggunakan rumus sebagai berikut.

$$
W m=W t-W o
$$

Keterangan:

$\mathrm{Wm}=$ Pertumbuhan berat benih ikan

$\mathrm{Wt}=$ Berat benih ikan pada akhir penelitian

Wo = Berat benih ikan pada awal penelitian

3. Kelangsungan hidup/Survival Rate (SR) menurut (Effendi 2004), untuk mengetahui tingkat kelangsungan hidup ikan yaitu dengan menggunakan rumus sebagai berikut:

SRBenih $=\frac{\text { Jumlah benih ikan pada akhir pemeliharaan }}{\text { Jumlah benih ikan pada awal pemeliharaan }} \times 100 \%$

Data diolah dengan analisa $\mathrm{F}$ dilanjutkan dengan uji $\mathrm{F}$ table dengan $\mathrm{F}$ hitung. Bila $\mathrm{F}$ Hitung < F Tabel 5\% dan 1\%, maka tidak dilanjutkan uji lanjutan. Bila sebaliknya, maka dilanjutkan dengan uji beda nyata terkecil (BNT) dan juga yang disajikan dalam bentuk histogram.

\section{HASIL}

\section{Hasil PertumbuhanPanjang}

Hasil yang didapat dari pengamatan terhadap pertumbuhan panjang benih ikan betok (A. testudineus) dapat di lihat pada Gambar 1.

Pertumbuhan panjang benih ikan betok selama pemeliharaan yang tertinggi terdapat pada perlakuan $\mathrm{V}_{3}$, yaitu penambahan kombinasi vitamin $C$ dan $D$ sebesar 4,61 $\mathrm{cm}$ sedangkan pertumbuhan panjang terendah terdapat pada perlakuan $\mathrm{V}_{1}$ yaitu penambahan vitamin $\mathrm{D}$ sebesar $3,85 \mathrm{~cm}$ (Gambar 1). Pertumbuhan panjang (Gambar 2) terlihat bahwa penambahan vitamin pada semua perlakuan terjadi peningkatan selama 60 hari pemeliharaan. Hasil analisis sidik ragam menunjukkan bahwa perlakuan penambahan vitamin pada pakan berpengaruh nyata terhadap pertumbuhan panjang benih ikan betok. Untuk melihat perlakuan mana yang berbeda nyata dilakukan uji lanjut beda nyata terkecil. Dari hasil pengujian lanjutan didapatkan hasil bahwa Penambahan vitamin $\mathrm{D}$ dan $\mathrm{C}$ berbeda nyata terhadap perlakuan lainnya (Tabel 1).

Tabel 1. Hasil Uji BNT pertumbuhan panjang benih ikan betok

\begin{tabular}{ccc}
\hline Perlakuan & $\begin{array}{c}\text { Rata-rata } \\
\text { panjang }\end{array}$ & $\begin{array}{c}\text { BNT 0,05 } \\
=0,45\end{array}$ \\
\hline $\mathrm{V}_{1}$ & 3,70 & $\mathrm{a}$ \\
$\mathrm{V}_{2}$ & 3,85 & $\mathrm{a}$ \\
$\mathrm{V}_{3}$ & 4,61 & $\mathrm{~b}$ \\
\hline
\end{tabular}

\section{Pertumbuhan Berat}

Hasil yang didapat dari pengamatan terhadap pertumbuhan berat benih ikan betok (A. testudineus) dapat di lihat pada Gambar 3.

Pertumbuhan berat benih ikan betok selama pemeliharaan yang tertinggi terdapat pada perlakuan $\mathrm{V}_{3}$ dengan penambahan vitamin $\mathrm{D}$ dan $\mathrm{C}$ sebesar 3,89 g, sedangkan pertumbuhan berat terndah pada $\mathrm{V}_{1}$ dengan penambahan vitamin $\mathrm{D}$ sebesar 2,70 $\mathrm{g}$ 
(Gambar 3). Pertumbuhan berat (Gambar 4) terlihat bahwa penambahan vitamin pada semua perlakuan terjadi peningkatan selama 60 hari pemeliharaan.

Selanjutnya dilakukan perhitungan analisis sidik ragam, dari perhitungan analisis sidik ragam menunjukkan bahwa perlakuan pemberian vitamin berbeda pada pakan berpengaruh nyata terhadap pertumbuhan berat benih ikan betok, untuk itu melihat perlakuan mana yang berbeda maka dilakukan uji lanjut. Tabel 2 menunjukkan hasil analisa lanjutan dimana setiap perlakuan menunjukkan perbedaan yang nyata pada setiap perlakuan.

Tabel 2. Hasil Uji BNT pertumbuhan berat benih ikan betok.

\begin{tabular}{ccc}
\hline Perlakuan & $\begin{array}{c}\text { Rata-rata } \\
\text { Panjang }\end{array}$ & $\begin{array}{c}\text { BNT 0,05 } \\
=0,32\end{array}$ \\
\hline V1 & 2,70 & $\mathrm{a}$ \\
V2 & 3,25 & $\mathrm{~b}$ \\
V3 & 3,89 & $\mathrm{c}$ \\
\hline
\end{tabular}

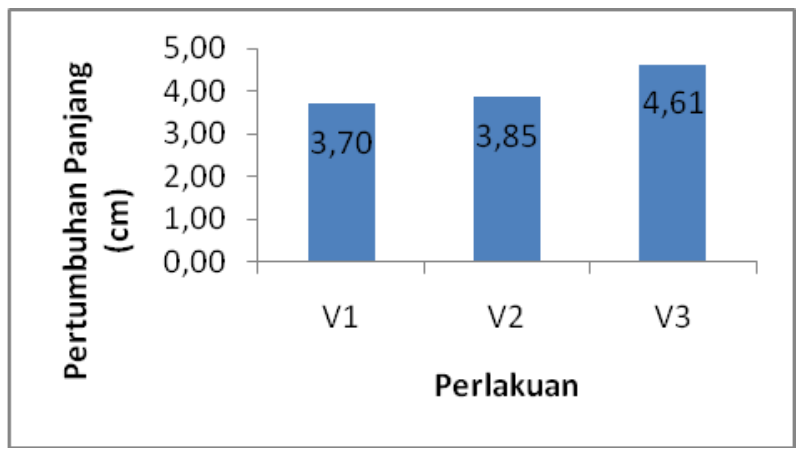

Gambar 1. Grafik pertumbuhan panjang larva ikan betok selama penelitian.

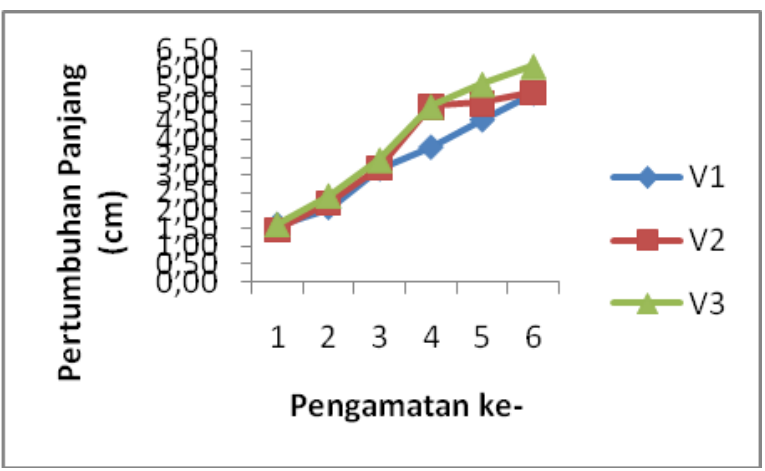

Gambar 2. Grafik pertumbuhan panjang larva ikan betok selama penelitian.

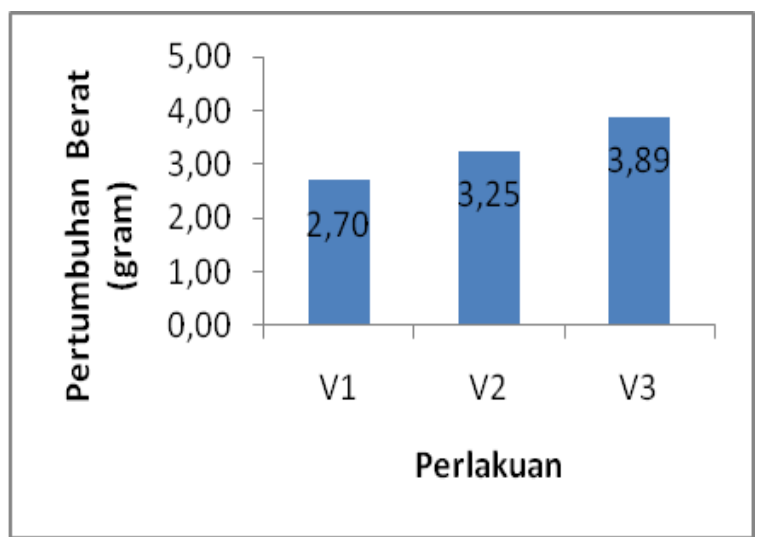

Gambar 3. Grafik pertumbuhan berat larva ikan betok selama penelitian 


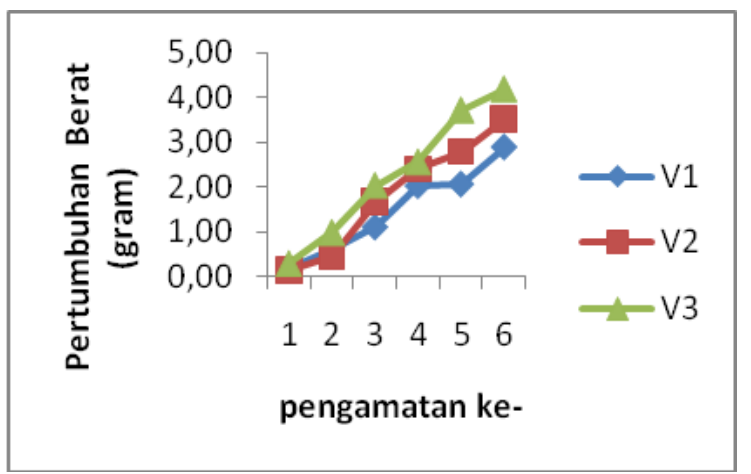

Gambar 4. Pertumbuhan berat larva ikan betook selama penelitian.

\section{Kelangsungan Hidup}

Hasil yang didapat dari pengamatan terhadap kelangsungan hidup benih ikan betok (A. testudineus) ditunjukkan pada Gambar 5.

Dari Gambar 5, menunjukkan bahwa kelangsungan hidup benih ikan betok selama pemeliharaan yang tertinggi terdapat pada perlakuan $\mathrm{V}_{3}$ sebesar 88,33\%, sedangkan kelangsungan hidup benih ikan betok terendah terdapat pada perlakuan $\mathrm{V}_{2}$ yaitu penambahan vitamin $\mathrm{C}$ sebesar $83,33 \%$.

Selanjutnya dilakukan perhitungan analisis sidik ragam. Dari perhitungan analisis sidik ragam menunjukkan bahwa perlakuan pemberian penambahan vitamin dengan dosis yang berbeda pada pakan tidak berpengaruh nyata terhadap kelangsungan hidup benih ikan betok. Sehingga karena perlakuan tidak berpengaruh nyata maka tidak dilakukan uji lanjut.
Selama pemeliharaan ikan betok yang diberi suplemen pada pakan, kualitas air selalu diukur guna mengetahui kondisi air sebagai media pemeliharaan. Hasil pengukuran (Tabel 3).

Tabel 3. Hasil pengukuran kualitas air selama pemeliharaan

\begin{tabular}{lc}
\hline \multicolumn{1}{c}{ Parameter } & Nilai \\
\hline Suhu $\left({ }^{\circ} \mathrm{C}\right)$ & $28-29$ \\
pH & $7,4-7,8$ \\
Oksigen Terlarut $\left(\mathrm{mgL}^{-1}\right)$ & $3,4-3,8$ \\
Amoniak $\left(\mathrm{mgL}^{-1}\right)$ & 0,19 \\
\hline
\end{tabular}

Sumber: Pengolahan data primer

\section{PEMBAHASAN}

\section{Pertumbuhan Panjang dan Berat}

Berdasarkan hasil penelitian menunjukkan pertumbuhan panjang dan berat tertinggi terdapat pada perlakuan $\mathrm{V}_{3}$ dengan penambahan kombinasi vitamin $\mathrm{C}$ dan vitamin D (Gambar 6).

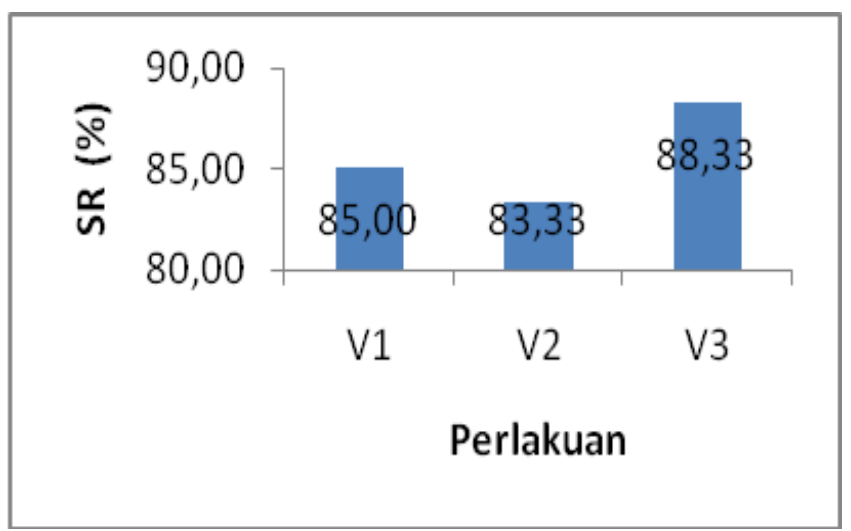

Gambar 5. Kelangsungan hidup larva ikan betok selama penelitian. 


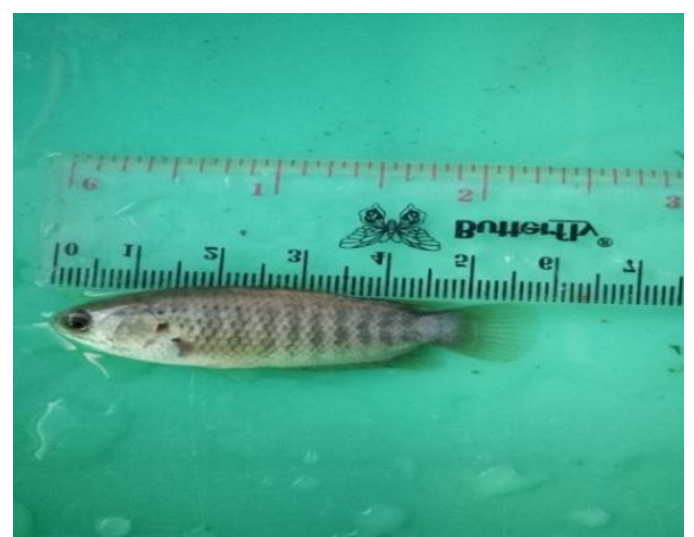

Gambar 6. Pengukuran pertumbuhan panjang ikan betok hasil penambahan vitamin.

Hal ini diduga bahwa vitamin $\mathrm{C}$ dan $\mathrm{D}$ yang diberikan didalam pakan digunakan oleh ikan untuk proses metabolismenya, sehingga pakan dengan pemberian kombinasi vitamin $\mathrm{C}$ dan $\mathrm{D}$ yang dikonsumsi dimanfaatkan ikan untuk pertumbuhannya. Hal ini sependapat dengan pernyataan (Tan dan $\mathrm{He}$ 2007) bahwa vitamin $\mathrm{C}$ dibutuhkan oleh ikan untuk metabolisme dalam tubuh untuk pertumbuhan, selain ituVitamin C pada ikan milkfish, Chanos chanos digunakan untuk memproduksi telur dan larva. Menurut Pamungkas et al. 2007, vitamin C mempunyai peranan penting dalam reaksi hidroksilasi prolin dan lisin yang merupakan senyawa penting dalam perkembangan tulang muda dan pembentukan kalogen. Pertumbuhan tulang yang tidak sempurna disebabkan oleh jaringan pelekat yang melemah dikarenakan pertumbuhan kalogen yang terhambat. Selain itu peran vitamin $\mathrm{C}$ juga untuk meningkatkan kekebalan tubuh terhadap serangan patogen, mencegah pertumbuhan tulang yang tidak sempurna dan membantu proses metabolisme dan fisiologi ikan. Menurut (Kato et al. 1994) bahwa ikan yang mengalami kekurangan vitamin $\mathrm{C}$ (defesiensi) akan mengalami berbagai gejala penyakit seperti berenang tanpa arah, warna tubuh pucat dan pendarahan padapermukaan tubuh, anemia dan peningkatan mortalitas. Vitamin $\mathrm{C}$ mutlak dibutuhkan dalam tubuh ikan, karena proses fisiologisnya dalam membantu metabolisme tubuh. Jika vitamin $\mathrm{C}$ cukup tersedia dalam tubuh, maka proses kolagenasi akan sempurna dan pertumbuhan akan lebih baik dan cepat (Gunawan et al. 2014). Umumnya Ikan tidak mampu mensintensis vitamin $C$ sehingga untuk mempertahankan metabolisme sel, vitamin $\mathrm{C}$ mutlak harus diperoleh dari luar tubuh karena tidak terdapat enzim L-gulonolakton oksidase yang dibutuhkan untuk biosintesis vitamin C (Farida et al. 2014).

Selain itu pada pakan juga dicampurkan vitamin $\mathrm{D}$, dimana vitamin $\mathrm{D}$ ini berperan dalam homeostatis kalsium yang berhubungan dengan mineralisasi gigi dan tulang serta menunjang proses metabolisme dari mineral terutama kalsium dan fosfor. Zainudin (2010) menyatakan bahwa difesiensi fosfor akan berakibat pada pertumbuhan yang lambat, kadar abu yang rendah, mineralisasi tulang yang buruk, tingginya kandungan lipid pada tubuh serta efesiensi pakan yang jelek. Sumber vitamin D terbesar didapatkan pada sinar matahari. Paparan sinar matahari dapat mempengaruhi metabolisme vitamin D (Setiati 2008). Selain dari sinar matahari, vitamin $\mathrm{D}$ juga bisa didapatkan dari makanan yang mengandung zat tersebut. Kekurangan vitamin D dapat mengakibatkan menurunnya massa otot dan juga mineralisasi pada tulang akan terganggu.

Penggunaan vitamin D dalam penelitian ini bertujuan untuk menunjang kebutuhan nutrisi dalam pakan ikan agar pertumbuhan yang dicapai oleh ikan optimal. Vitamin D adalah salah satu 
vitamin larut lemak prohormon yang juga dikenal dengan nama kalsiferol. Vitamin D sendiri memiliki 2 bentuk aktif yaitu vitamin D2 dan D3. Fungsi dari vitamin D ini yaitu membantu pembentukan dan pemeliharaan tulang. Sementara fungsi khusus dari vitamin D adalah membantu pengerasan tulang, caranya dengan mengatur agar kalsium dan fosfor tersedia didalam darah dan kemudian diendapkan pada proses pengerasan tulang (Nainggolan dan Ningsih 2015)

Helmizuryani (2013) menyatakan ketersediaan pakan dapat mempengaruhi pertumbuhan dan kelangsungan hidup ikan yang dipelihara. Vitamin sangat diperlukan oleh tubuh untuk menjalankan berbagai fungsi metabolisme, namun jika terjadi kelebihan vitamin akan mengakibatkan hipervitaminosis, hipervitaminosis merupakan suatu istilah yang merujuk pada kadar abdormal vitamin pada tubuh hingga dapat menyebabkan keracunan. Vitamin D yang berlebihan atau dalam jumlah banyak dapat mengakibatkan gangguan saluran pencernaan, rapuh tulang, gangguan pertumbuhan dan keterlambatan perkembangan, sedangkan menurut (Paul et al. 2017) Vitamin D dibandingkan dengan vitamin lainnya menghasilkan pertumbuhan signifikan untuk ikan yang berukuran kecil

Jusadi (2006) mengatakan bahwa peningkatkan ketahanan tubuh dapat membantu proses pertumbuhan dengan penambahan vitamin $\mathrm{C}$ dalam jumlah yang tepat agar kualitas pakan menjadi meningkat Hal ini sependapat dengan, (Siregar dan Adelina 2009) menyatakan bahwa vitamin $\mathrm{C}$ yang diberi secara berlebihan tidak semuanya diserap oleh tubuh, namun akan dikeluarkan dalam bentuk urin, serta berlebihnya asupan vitamin $\mathrm{C}$ akan mengakibatkan diferensiasi vitamin $B_{12}$ yang salah satu perannya sebagai pembentuk jaringan baru.

Kalsium merupakan unsur yang esensial dalam proses pertumbuhan. Akan tetapi bukan hanya mineral kalsium saja yang dibutuhkan oleh tulang tetepi juga vitamin D. Tubuh tidak bisa menyerap kalsium sama sekali tanpa kehadiran vitamin D yang cukup di dalam tubuh. Saatvitamin D masuk, tubuh akan langsung mengubahnya menjadi hormon kalsiferol yang akan membantu penyerapan kalsium dari usus. Sementara itu, vitamin C seperti yang sudah dijelaskan sebelumnya memiliki fungsi dalam menjaga kondisi tubuh dan berperan dalam kerja sistem metabolisme tubuh (Vera et al. 2015). Dengan kombinasi kedua vitamin, maka kinerja tubuh dalam metabolisme akan makin baik. Penyerapan zat esensial akan berjalan dengan baik, serta metabolisme tubuh tidak terganggu karena kekurangan zat tertentu. Maka dari itu dengan mengkombinasikan kedua jenis vitamin diharapkan dapat meningkatkan dan saling melengkapi kebutuhan ikan untuk tumbuh dan berkembang. Dari hasil penelitian dosis 375/mg vitamin $\mathrm{C}$ dan 125/mg vitamin D menunjukan respon pertumbuhan yang baik dan tidak menyebabkan hipervitaminosis pada tubuh ikan.

\section{Kelangsungan Hidup}

Derajat kelangsungan hidup dapat digunakan sebagai salah satu indikator keberhasilan suatu kegiatan budidaya ikan.Jika diperoleh nilai SR yang tinggi pada suatu kegiatan budidaya, maka dapat dikatakan bahwa kegiatan budidaya yang dilakukan telah berhasil dan sebaliknya jika diperoleh nilai SR yang rendah maka kegiatan budidaya kurang berhasil. Salah satu faktor yang menentukan kelangsungan hidup ikan adalah pakan, pemberian pakanyang cukup kuantitas dan kualitas akan meningkatkan kelangsungan hidup ikan yang dipelihara, sebaliknya kekurangan pakan akan berdampak terhadap kesehatan ikan dan akan menurunkan kelangsungan hidup ikan yang dipelihara.

Selama penelitian penambahan vitamin berbeda pada pakan pelet tidak berpengaruh nyata terhadap kelangsungan hidup benih ikan betok. Namun secara tabulasi nilai kelangsungan hidup tertinggi terdapat pada pada perlakuan V3 dengan 
penambahan vitamin $\mathrm{D}$ dan $\mathrm{C}$, hal ini disebabkan ketersediaan pakan dan pakan yang diberikan memiliki kandungan gizi yang sesuai untuk kebutuhan hidup ikan, seperti protein, lemak, karbohidrat, vitamin dan mineral. Penambahan vitamin D dan C pada pakan menjadikan pertumbuhan dan kelangsungan hidup benih ikan betok menjadi lebih baik, menurut (Gunawan, Subandiyono dan Pinandoyo 2014) bahwa vitamin $\mathrm{C}$ dapat meningkatkan daya tahan tubuh dan menghindari stres pada stadium benih sehingga kelangsungan hidupnya meningkat, selanjutnya (Baynes et al. 1997) menyatakan bahwa manfaat vitamin D jauh melebihi itu, selain untuk kesehatan tulang vitamin D juga terbukti dapat membantu menjaga sistem kekebalan tubuh dan vitamin $\mathrm{C}$ dibutuhkan oleh tubuh ikan untuk meningkatkan metabolisme, daya tahan terhadap perubahan lingkungan dan penyakit. Nutrisi dalam pakan merupakan faktor utama yang diperlukan dalam pertumbuhan dan meningkatkan tingkat kelangsungan hidup. Helmizuryani dan Muslimin (2016) menjelaskan bahwa apabila energi dalam pakan terlalu tinggi akan menurunkan konsumsi pakan, selanjutnya asupan nutrien menjadi pakan sehingga ikan sulit untuk bertahan hidup.

Kelulushidupan ikan dipengaruhi oleh faktor biotik dan abiotik. Salah satu faktor abiotik yang dibutuhkan adalah ketersediaan komponen gizi dalam pakan ikan. Salah satu komponen tersebut adalah vitamin yang berperan dalam meningkatkan kelulushidupan ikan adalah vitamin $\mathrm{C}$. Vitamin $\mathrm{C}$ merupakan senyawa organik yang berperan penting dalam proses metabolisme makanan dan fisiologi ikan. Walaupun bukan merupakan sebagai sumber tenaga tetapi vitamin $\mathrm{C}$, dibutuhkan sebagai katalisator terjadinya metabolisme di dalam tubuh (Siregar dan Adelina 2009).

Kelangsungan hidup benih ikan Betok selama 60 hari pemeliharaan pada semua perlakuan berkisar antara $83,33 \%$ dan nilai tersebut termasuk tinggi bila dibandingkan dengan hasil penelitian (Duangjai et al. 2017), dengan pemberian suplemen vitamin $\mathrm{A}, \mathrm{D}, \mathrm{E}$, dan $\mathrm{K}$ yang mencapai 82\% dan (Alam et al. 2010) tanpa penambahan vitamin sebesar $74-85 \%$. Di samping itu lingkungan tempat ikan dipelihara juga mendukung untuk kehidupan benih ikan betook. Helmizuryani dan Muslimin (2015) mengatakan bahwa tingkat keberlangsungan hidup merupakan keberlangsungan pertumbuhan ikan betok terhadap pemberian jenis makanan. Hal ini didukung oleh media tempat hidup benih ikan betok dan ketersedian makanan masih dalam batas toleransi. Namun, dalam pemberian pakan, harus juga disesuaikan dengan kualitas pakan yang dapat mempengaruhi kualitas air.

\section{KESIMPULAN}

Berdasarkan hasil penelitian yang dilakukan, dapat diambil kesimpulan bahwa penambahan kombinasi vitamin $\mathrm{D}$ dan $\mathrm{C}$ pada pakan memberi respon terbaik terhadap pertumbuhan dan kelangsungan hidup benih ikan betok (A. testudineus) dimana pertumbuhan berat sebesar 3,89 g, pertumbuhan panjang sebesar $4,61 \mathrm{~cm}$, dan kelangsungan hidup sebesar $88,33 \%$.

\section{UCAPAN TERIMA KASIH}

Penulis menyampaikan terima kasih kepada Bapak Rektor Universitas Muhammadiyah Palembang yang telah memfasilitasi berjalannya penelitian ini.

\section{DAFTAR PUSTAKA}

Alam J, Mustafa G, Islam M. 2010. Effects of some artificial diets on the growth performance, survival rate and biomass of the fry of climbing perch, Anabas testudineus (Bloch, 1792). Nature and Science 8(2): 3642.

Asyari. 2007. Pentingnya labirin bagi ikan rawa. Jurnal Bawal: Widya Riset Perikanan Tangkap 1(5):161-167.

Duangjai E, Tanathip S, Punroob J. 2017. The effect of vitamins A, D, dan E 
supplementation on the growth, reproductive performance and survival rates of climbing perch Anabas testudineus broodstock in cage culture environments', SNRU Journal of Science and Technology 9(1): 379-388.

Farida, Hasan, Dayanti. 2014. Pengaruh vitamin $\mathrm{C}$ dalam pakan terhadap pertumbuhan dan sintasan benih ikan biawan. Jurnal Ruaya 3.

Gunawan, Subandiyono, Pinandoyo. 2014. Pengaruh vitamin $\mathrm{c}$ dalam pakan buatan terhadap tingkat konsumsi pakan dan pertumbuhan ikan nila merah (Oreochromis niloticus). Journal of Aquaculture Management and Technology 3:191-198.

Helmizuryani. 2013. Analisis biologi reproduksi ikan betok (Anabas testudineus) dari perairan alam. Fisheries 1:35-39.

Helmizuryani, Muslimin B. 2015. Efesiensi pakan dengan kadar protein yang berbeda pada ikan betok (Anabas testudineus). Dalam Seminar Nasional Sains \& Teknologi VI, pp. 607-622.

Helmizuryani, Muslimin B. 2016. Growth performance of mono sex and mixed sex climbing perch (Anabas testudineus). Omni-Akuatika 12: 99103.

Helmizuryani, Muslimin B, Khotimah K. 2017. Pembetinaan ikan betok, Anabas testudineus (Bloch 1792) menggunakan larutan susu dan kedelai melalui perendaman larva. 17(2):123-132.

Pamungkas W. 2007. Pengaruh itamin C terhadap perkembangan gonad induk udang galah (Macrobrachium rosenbergii). 2:194-199.

Prianto E. 2014. Biologi reproduksi ikan betok (Anabas testudineus) di Paparan Banjiran Lubuk Lampam, Kabupaten Ogan Komering Ilir, Bawal 6(3):137-146.

Setiati S. 2008. Pengaruh pajanan sinar ultraviolet B bersumber dari sinar matahari terhadap konsentrasi vitamin $\mathrm{D}$ dan hormon paratiroit pada perempuan usia lanjut Indonesia. Kesehatan Masyarakat Nasional 2(4):147-153.

Siregar YI, Adelina D. 2009. Pengaruh vitamin $\mathrm{C}$ terhadap peningkatan hemoglobin $(\mathrm{Hb})$ Darah dan Kelulushidupan Benih Ikan Kerapu Bebek (Cromileptes altivelis). Jurnal Natur Indonesia 75(121):7581.

Sunarto, Suriansyah, Sabariah. 2008. Pengaruh pemberian vitamin $\mathrm{C}$ ascorbic acid terhadap kinerja pertumbuhan dan respon imun ikan betok Anabas testudineus Bloch. 7(2): 151-157.

Vera, Setiati S, Arya G. 2015. Determinan diagnostik klinis defisiensi vitamin D pada wanita berusia lebih dari 50 tahun. Jurnal Penyakit dalam Indonesia 2(1):38-48.

Zainudin. 2010. Pengaruh calsium dan fosfor terhadap pertumbuhan, efisiensi pakan, kandungan mineral dan komposisi tubuh juvenil ikan kerapu macan. 2(2):1-9.

Zulkarnain ALH. 2017. Pengaruh penambahan vitamin $\mathrm{C}$ pada pakan sebagai imunostimulan terhadap performa darah, kelulushidupan, dan pertumbuhan ikan tawes (Puntius javanicus). 3:174-182. 